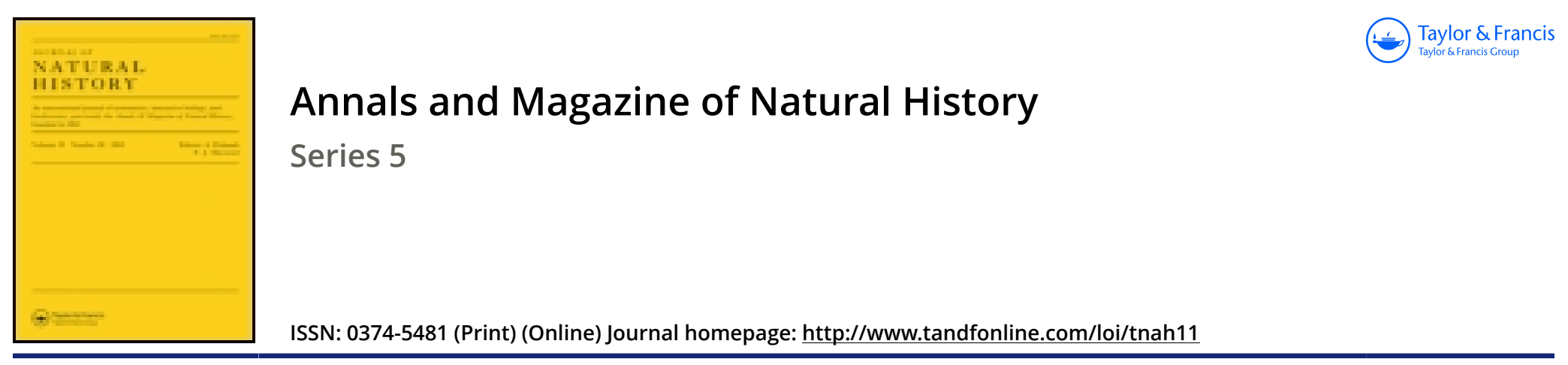

\title{
XV.-Description of a new genus and species of longicorn Coleoptera from the Philippine Islands
}

\section{Charles O. Waterhouse}

To cite this article: Charles O. Waterhouse (1884) XV.-Description of a new genus and species of longicorn Coleoptera from the Philippine Islands, Annals and Magazine of Natural History, 13:74, 128-129, DOI: $10.1080 / 00222938409459210$

To link to this article: http://dx.doi.org/10.1080/00222938409459210

\section{Published online: 07 Oct 2009.}

\section{Submit your article to this journal $\square$}

Џ Article views: 3 


\section{XV.-Description of a new Genus and Speries of Longicorn Coleoptera from the Philippine Islands. By Charles (). WATERHOUSE.}

\section{Lamiidæ.}

\section{Apontecynine.}

Diaxenes, n. gen.

General characters of Apomecyna, but a little less parallel in outline, the elytra being more narrowed towards the apex. Antennal tubercles a little more prominent and more approximate; face equilateral, very gently convex. Eyes coarsely granular, not quite so deeply emarginate. Antennæ reaching two thirds of the length of the elytra, moderately stout, finely ciliate below; the basal joint three times as long as broad, only very slightly narrowed at the base; third a little longer than the first and second taken together, slightly bent, and distinctly narrower at the base than at the apex; fourth joint three quarters the length of the third; the fifth a little more than half the length of the fourth; the following joints gradually but only slightly diminishing in length and thickness. Thorax a little broader than long, subcylindric, a little narrowed in front. Scutellum transverse. Elytra at the base one quarter broader than the thorax, not quite four times as long, moderately narrowed towards the apex, flattened at the suture; at the base, gradually declivous from just behind the middle the apex of each elytron obliquely truncate. Legs short and stout; the femora considerably inflated. Intermediate tibiæ with an incision on the outer edge at the apex. Tarsi short; claws diverging. Prosternal process sloping down posteriorly. Mesosternal process rather broader than the prosternal, sloping down in front.

The species on which I propose to found this genus very much resembles some of the smaller species of Hathliodes. It differs from Apomecyna chiefly in the proportions of the antennal joints (which also diminish in thickness and are ciliate), the even surface of the thorax, and less parallel form.

\section{Diaxenes Taylori, n. sp.}

Pube pallide flavo-grisea dense vestitus ; antennarum dimidio apicali fusco, articulis griseo annulatis; thorace ad basin gutta alba notato ; scutello fusco, gutta mediana lateribusque albis ; elytris ante medium prope suturam gutta fusca; abdomine fusco-rittato, 
guttis albis utrinque ornato; femorum basi, tibiarum apice tarsisque nigris.

Long. $5 \frac{1}{4}$ lin.

The general colour is a pale sandy, with a slightly darker shade at the base and apex of the elytra. Scattered more or less all over the body, including the basal joint of the antennæ and the legs, there are erect white setæ. There are a few distinct punctures on the head between the antennæ. The fourth to the apical joints of the antennæ are blackish brown, with the base of each joint pale. The thorax is very slightly broader than long, moderately narrowed in front of the middle, with a very slight constriction at the base, the sides very gently arcuate; near the base there are a few very distinct punctures; on the basal margin on each side there is a very small fuscous spot. The elytra have the shoulders rounded; some punctuation is visible through the pubescence, there are some small black punctures here and there, and near the scutellum there are numerous larger dark punctures. There is a brown patch on each side of each abdominal segment, and in each patch a small white spot. The legs are nearly white, with the base of the femora dark; the apex of the tibiæ and the tarsi nearly black.

Hab. Philippine Islands? Brit. Mus.

The specimen from which the above description is taken was found alive in the Royal Nursery, Chelsea, on a species of Orchis (Phalcenopsis) from Manilla; it was gnawing off the stems of the plant.

British Museum, Cromwell Road, S.W.

XVI.-Generic Characters of the Sponges described in Mr. Carter's "Contributions to our Knowledge of" the Spongida" ('Annals,' 1883, vol. xii. p. 308). By THE Author.

\section{Order III. PSAMMONEMATA.}

Family 1. Surface even, not polygonally divided.

Genus Coscinoderma, Crtr.

Char. Sieve-like incrustation, composed of foreign bodies, 